\title{
Geophysical and Hydrological Investigations of the Northern Wadis Area of Azraq Basin for Groundwater Artificial Recharge Purposes
}

\author{
Hani Al-Amoush1*, Abdel Rahman Al-Shabeeb ${ }^{1}$, Saad Al-Ayyash ${ }^{2}$, Rida Al-Adamat ${ }^{1}$, \\ Majed Ibrahim', A'kif Al-Fugara², Jaafar Abu Rajab ${ }^{3}$ \\ ${ }^{1}$ Institute of Earth and Environmental Sciences, Al al-Bayt University, Mafraq, Jordan \\ ${ }^{2}$ Faculty of Engineering, Al al-Bayt University, Mafraq, Jordan \\ ${ }^{3}$ Natural Resources Faculty, Hashemite University, Zarqa, Jordan \\ Email: "hani1@aabu.edu.jo
}

Received 11 April 2016; accepted 23 May 2016; published 27 May 2016

Copyright (C) 2016 by authors and Scientific Research Publishing Inc.

This work is licensed under the Creative Commons Attribution International License (CC BY). http://creativecommons.org/licenses/by/4.0/

c) (i) Open Access

\begin{abstract}
Geophysical study and watershed hydrological delineation have been integrated at downstream of Alasra dam site Norh Azraq area to investigate their potential for artificial groundwater recharge. The total surface area of the watershed was found to be about 195 square kilometers. The estimated annual runoff volumes for the Alasra watershed ranged between 1.2 and 1.8 MCM. Moreover, the interpretation of Ten Time Domain Electromagnetic (TDEM) soundings suggested three principal subsurface layers. The top surface layer has an intermediate resistivity (90 - 110 0hm·m) with a thickness ranging from a few meters to around $50 \mathrm{~m}$. This layer was interpreted as superficial deposits. The second subsurface layer with variably high resistivity values is composed of unsaturated massive basalt layer and probably belongs to Madhala Olivine Phyric Basalt Formation (MOB). The large variations in resistivity could be ascribed to the degree of water saturation (as a result of groundwater recharge from the nearby harvested water dam), or lithological variations (clay content) and/or due to structural control. The third subsurface layer has low resistivity values $(<10 \Omega \cdot \mathrm{m}$ to $40 \Omega \cdot \mathrm{m})$ and was found at a depth ranging from 120 to $150 \mathrm{~m}$. This layer could represent a saturated basalt layer with high clay contents. The subsurface structures and major faults have been identified. Based on the results of this study, a combination of surface and subsurface artificial groundwater recharge techniques is highly recommended.
\end{abstract}

${ }^{*}$ Corresponding author.

How to cite this paper: Al-Amoush, H., Al-Shabeeb, A.R., Al-Ayyash, S., Al-Adamat, R., Ibrahim, M., Al-Fugara, A. and Rajab, J.A. (2016) Geophysical and Hydrological Investigations of the Northern Wadis Area of Azraq Basin for Groundwater Artificial Recharge Purposes. International Journal of Geosciences, 7, 744-760. http://dx.doi.org/10.4236/ijg.2016.75057 


\section{Keywords}

\section{TDEM, Groundwater Recharge, Alasra, Hydrogeophysics, Azraq, Jordan}

\section{Introduction}

Jordan is located in an arid to semi-arid region with variable topography features. The far western part of the country is mountainous terrains, while the eastern and southeastern parts are dominated by flat-desert terrains. Due to these topographic variations, rainfall distribution varies considerably. The annual rainfall intensity ranges from $600 \mathrm{~mm}$ in the northwest to less than $50 \mathrm{~mm}$ in eastern and southern parts of the country [1]. Jordan is suffering from scarcity and shortage of water resources. The available per capita water resources are projected to decline from about $150 \mathrm{~m}^{3} /$ year to only $90 \mathrm{~m}^{3} /$ year by the year 2020, putting Jordan in the category of absolute water shortage [2]. The political situations in the region, especially the recent waves of Syrian refugees have added an extra pressure on the natural resources and in particular the water resources. During winter times, the eastern and desert areas received extensive rain storms and monsoons, by which, a large quantity of surface water are drained through wadis and spread over low lands, surface and flat areas and eventually lost to evaporation. In recent years, several studies have been conducted on water harvesting and capturing surface water in dams in the eastern and northeastern Jordan (e.g. [3]-[6]). During the last four decades, the groundwater table has declined dramatically due to the extensive pumping (either for domestic and agricultural activities). Groundwater artificial recharge is an effective technique to fill aquifers using different types of water, and to augment groundwater level. It has many advantages over water harvesting, as it is less affected by the climatic conditions and evaporation. In addition, the recharged water is subjected to self-purification (natural attenuation) which will be enhanced naturally through percolation. Groundwater artificial recharge studies have been done using different geophysical and GIS techniques in several areas worldwide as well as in Jordan (e.g. [4] [7]-[13]).

TDEM technique has been previously used in numerous hydrogeological applications (e.g. [14]-[21]). In this study, the TDEM technique and hydrological study were integrated to investigate the potentials for artificial groundwater recharge at the dam downstream area of at Alasra Dam site as a tool for conservation of the harvested and flooding water to be used at times of dry and hot summer seasons.

\section{Description of Study Area}

The investigated area- which is part of Jordan's eastern plateau - is located in the northwestern part of Azraq basin between [480000 - 492000] E, [550000 - 575000] N according to Jordan Transverse Mercator (JTM) (Figure 1). Relief topography of Alasra watershed area shows that the elevations are ranging from $740-1000 \mathrm{~m}$ above sea level (masl). The average annual rainfall varies from $70 \mathrm{~mm}$ in the far eastern and southern part of the study area to about $150 \mathrm{~mm}$ in the northwestern part. The temperature may reaches more than $40^{\circ} \mathrm{C}$ during summer days and drops to a few degrees below zero in winter, especially during the night [1]. The relative humidity in eastern plateau is low. In winter, it is generally around 50\% - 60\% and drops to $15 \%$ in summer [1]. The potential evaporation rates increase east and south-wards directions and may exceed $4000 \mathrm{~mm} / \mathrm{y}$ in the center of plateau [1].

\section{Geology of the Study Area}

The geological setting of Neogene continental basalts exposed at NE-Jordan have been investigated by several researchers (e.g. [22]-[35]). The study area is part of Harrat ash-sham Basalts super Group and forms the northern extension of Arabian Volcanic province [35]. A brief description of the major geological formations found in the study area (Figure 2) can be summarized as follows [35] [36].

\subsection{Abed Olivine Phyric Basalt Formation (AOB) (Safawi Group)}

It comprises thick and massive flow units up to $10 \mathrm{~m}$ with a total thickness of up to $100 \mathrm{~m}$. It contains several basaltic flood lava and feeder dike systems and is characterized by a massive, blocky and, columnar joint with polygon upper surfaces. There is a strong vesicularity in the upper part of the flow edifices. 


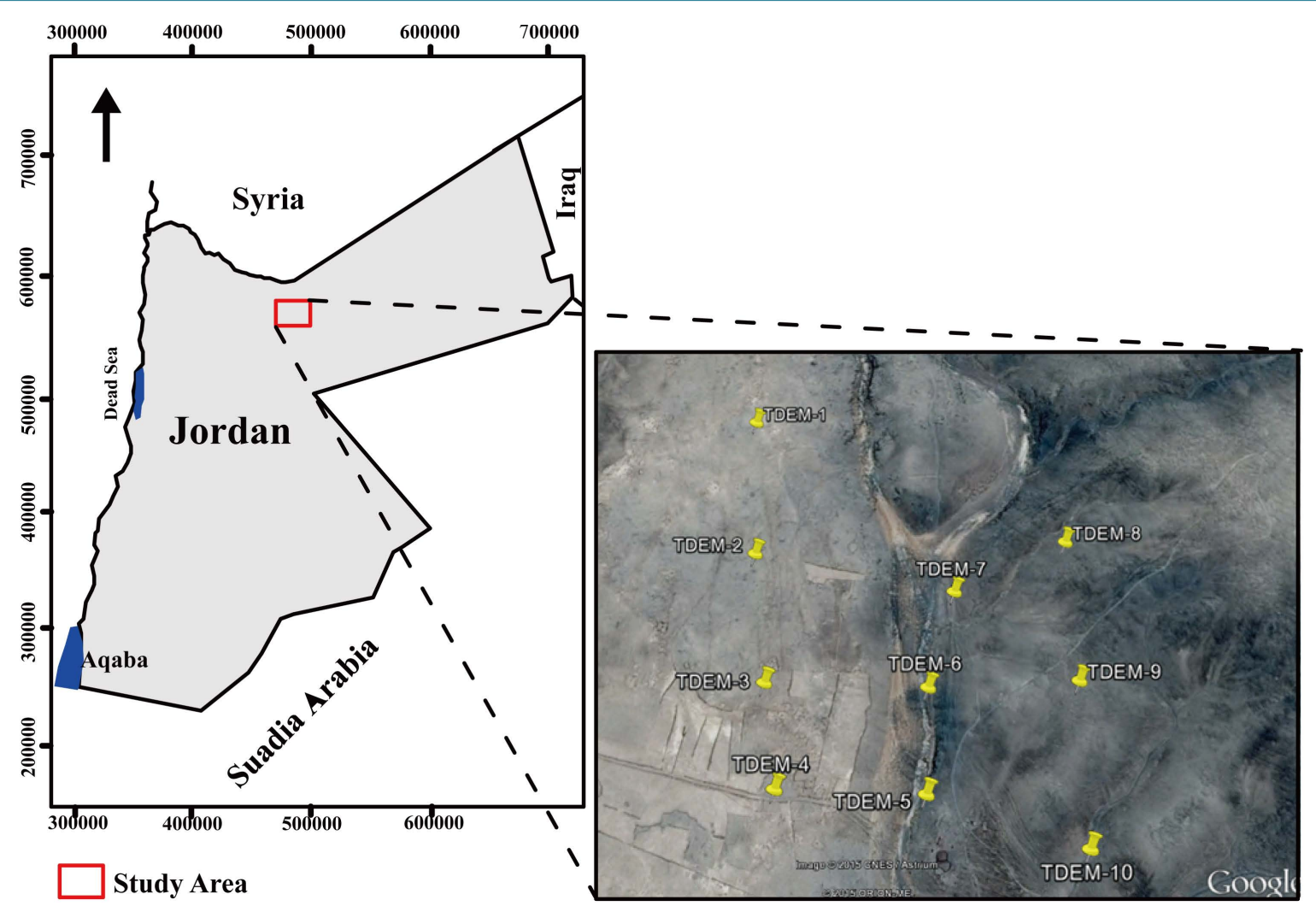

Figure 1. Location map of the study area and TDEM soundings sites on Google earth image. Coordinate system: Jordan Transverse Mercator (JTM).

\subsection{Ufayhim Xenolith Basalt Formation (UM) (Asfar Group)}

This formation was formed by eruption from the Jebel al Aritin volcano which flooded west- and south-wards along an old wadi. It typically displays well developed columnar jointing and non-systematic closely spaced horizontal jointing. It has host mantle xenolith.

\subsection{Ushayhib Olivine Pyroxene Phyric Basalt Formation (UB) (Asfar Group)}

Lava of the formation is extruded from the central vent of the Jabal Ushayhib volcano and the associated parasitic volcanoes. It forms an upstanding semi-vertical cliff above the plain of the Abed Olivine Phyric Basalt Formation (AOB) with up to $15 \mathrm{~m}$ thick.

\subsection{Hashimyya Aphanitic Basalt (HAB) (Asfar Group)}

Similar to Ufayhim Formation, the Hashimyya Formation typically displays columnar jointing, and less developed non-systematic closely spaced horizontal jointing. It is characterized by the presence of volcaniclastic deposits underneath. The thickness of Hashimyya Formation is less than $15 \mathrm{~m}$ and comprises thin flow units mostly ranges between 3 and $5 \mathrm{~m}$. it is characterized by the presence of amygdaloidal texture, where vesicles are filled with calcite.

\subsection{Madhala Olivine Phyric Basalt Formation (MOB) (Asfar Group)}

Lava of Madhala Olivine Phyric Basalt Formation erupted from volcanic vent centers, including shield volcanoes, composite volcano vents and cinder scoria cones in the area. Its thickness varies greatly and reaches its maximum $100 \mathrm{~m}$ around the volcanic vents. It is mainly consists of massive and bedded basalt with polygonal joints, vesicles are present. There are large similarities between its lithology and the Abed Olivine Phyric Basal Formation. 


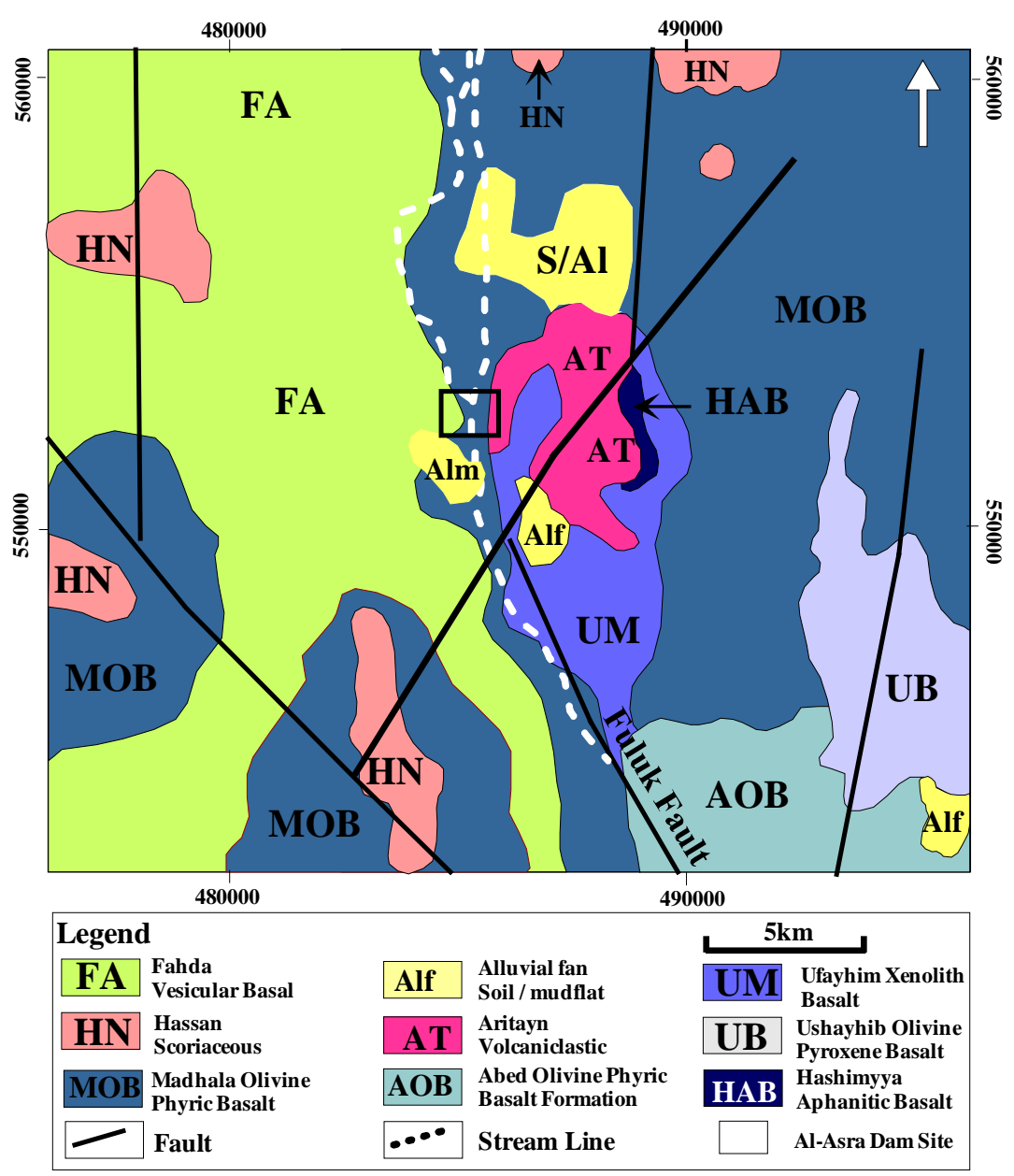

Figure 2. Geological map of the study area (modified after [36]).

\subsection{Mahadda Basalt Formation (M) (Asfar Group)}

It differs from the other units of the Asfar group in its hummocky and rough upper surface which comprises weathered wadi-fill lava with poorly preserved pressure ridges. The thickness of the formation varies from $10 \mathrm{~m}$ to $25 \mathrm{~m}$. It is lithologically similar to Madhala Olivine Phyric Basalt Formation.

\subsection{Hassan Scoriaceous Formation (HN) (Rimah Group)}

The 15 - 40 m deposits of Hassan Formation include bombs of lava spatter with various shapes along with coarse scoriaceous blocks. It is composed of poorly bedded, friable and very coarse-grained scoriaceous pyroclasts.

\subsection{Aritayn Volcaniclastic Formation (AT) (Rimah Group)}

The Aritayn Volcaniclastic Formation is developed from stratified cinder cones, occasionally composite. These pyroclastic deposits interbedded with lava flows. The formation consists of bedded, poorly cemented air-fall tephra, which is typified by its stratified form and typically cavernous. Similar to the Hassan formation, it is characterized by a smooth ground surface color. The boulder cover is mainly pyroclasts mixed with basaltic boulders.

\subsection{Bishriyya Group (BY)}

This group includes the youngest volcanism recorded in the study area. It is subdivided into two formations 
based on truncation flow lines which is a reflection of different ages, otherwise, the area is lithologically and morphological similar. These are Fahda Vesicular Basal Formation (FA) and Wadi Manasif Basalt Formation (WMF) which are not shown in the investigated area. The surface of the flows is characterized by a rubbly and very vesicular ground cover. Boulders are characterized by a purplish-black weathering color. They show a columnar jointing and exhibit typical polygonal lobes of pahoehoe lava types. This group has a thickness ranging from $25-60 \mathrm{~m}$.

\subsection{Superfacial Deposits}

\subsubsection{Alluvium and Wadi Sediments (Al)}

Alluvium and wadi sediments consist of gravels and, sand deposits.

\subsubsection{Alluvial Fans (Alf)}

Alluvial fans occur in two places, to the southeast of Jabal Al Aritin and south of Wadi Al Aritin. The fans are composed of stony, or sometimes boulder, deposits with arcuate low ridges of gravels, sand and silt.

\subsubsection{Alluvial Mudflats and Silt Flats (Alm)}

Several mudflats are surrounding the investigated area. They were probably formed as a result of regional and local faults which produced small depressions, where mud accumulated from standing water fed by ephemeral wades discharged into the mudflat. They consist of soft and silty clay and rock fragments.

\section{Data Acquisition and Modeling}

\subsection{Hydrology and Watershed Modeling}

The watershed model of Alasra site (Figure 3) was developed using the geographic information system (ArcGIS10.3), where the SRTM digital elevation data was used to delineate the boundaries of the watershed (its sub-basins and the wadi network within the watershed). The total area of the watershed was found to be about 195 square kilometers, extending northward (inside the Syrian border) to the south with a total length of about 40 kilometers.

A preliminary runoff investigation for part of Alasra site was conducted by [3]. The study showed that the average annual surface water which can be collected at the outlet of the watershed was $0.2 \mathrm{MCM}$. This quantity constitutes about $8 \%$ of the annual rainfall volume received by the watershed. In another study for the region, where the study area is located [37], the annual runoff coefficient varied between $5 \%$ and $8 \%$ with an average annual rainfall in the area of $120 \mathrm{~mm}$; given these figures, the annual runoff volume for the Alasra watershed could be estimated between 1.2 and 1.8 MCM.

\subsection{Time Domain Electromagnetic Method (TDEM)}

In the downstream of Alasra harvested dam site (Figure 1), TDEM soundings were conducted to characterize the subsurface layers and structures and to investigate their potentials for artificial groundwater recharge. The field geometry of the TDEM's soundings was gridded with 200 - $300 \mathrm{~m}$ spacing. This allows for obtaining different 2D resistivity models representing the subsurface resistivity variations with different directions. Table 1 lists the coordinates, elevations and root mean square error (RMSE) for each modeled TDEM soundings. The square transmitter loop was $50 \mathrm{~m} \times 50 \mathrm{~m}$ with estimated depth of about $130 \mathrm{~m}$. In TDEM theory, a direct current (DC) is transmitting through loop wire. This produces a static primary magnetic field. The current is shut off abruptly after a while, which due to Faraday's law induces an electrical field in the surroundings. In the ground, this will again produce a magnetic field; the secondary field. Since the secondary magnetic field is generated during the period when the primary magnetic field is off, it can be measured relatively easily. The decaying of the secondary magnetic field in conductive bodies is slower than that in poor conductors. Measurements of the rate of change (decay) of the secondary field thus provide a means of detecting subsurface conductive bodies and estimating their conductivities [38] [39]. The decaying transient signal is sampled at various time gates to yield a sounding apparent resistivity curve. In this study, ATEM FAST 48 HPC system has been used for data acquisition. The system was set to transmit current up to 4 Ampere using 12 Voltage source batteries with 48 active time gates $(15,360 \mu \mathrm{s}-\mathrm{t}$ center). The stacking time was set to about 7 minutes with $50 \mathrm{~Hz}$ noise filter in 


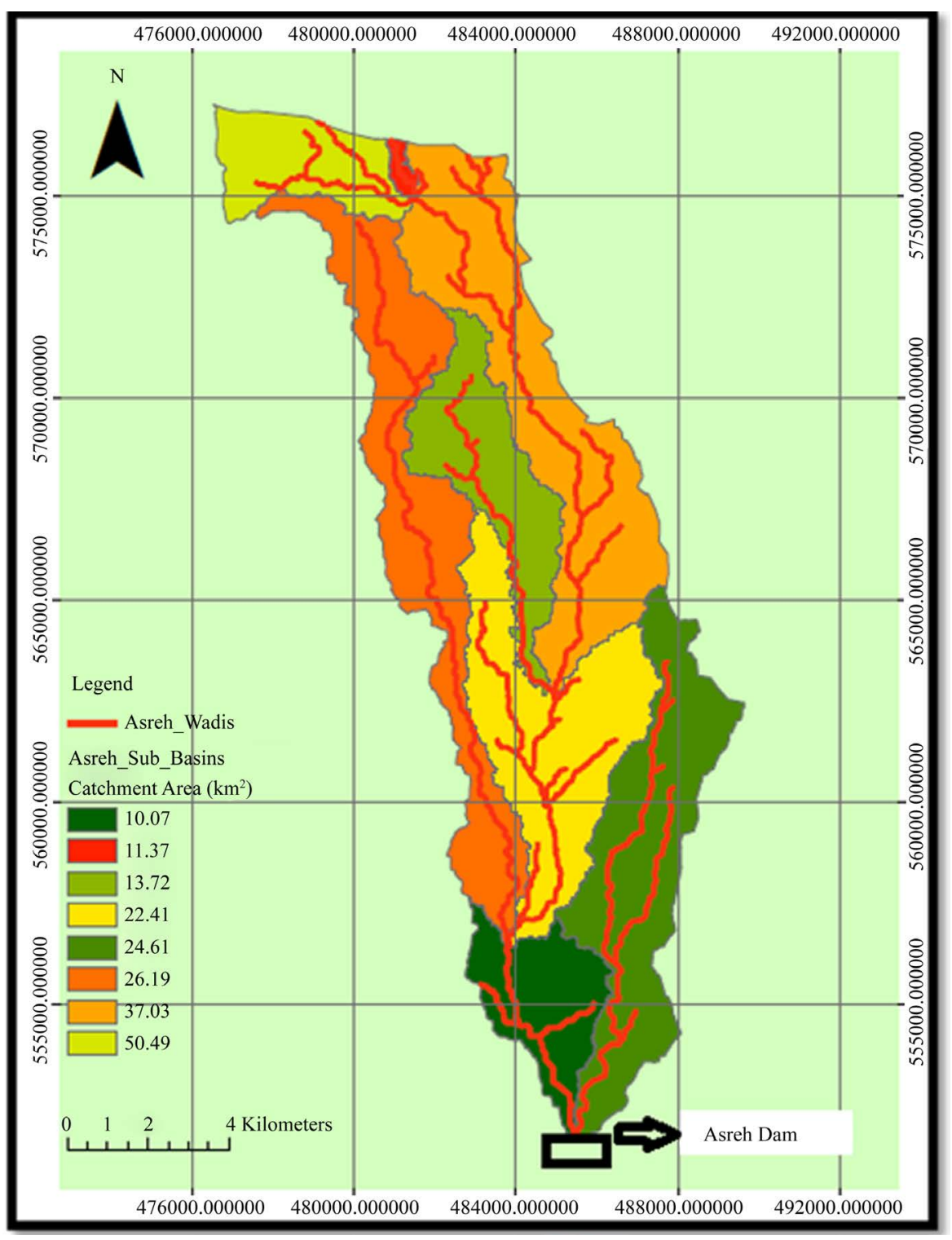

Figure 3. Watershed and sub-watershed areas of Alasra dam site.

Table 1. Coordinates, elevations and Root Mean Square Error (RMSE) of TDEM data.

\begin{tabular}{ccccc}
\hline Sounding & Longitude & Latitude & Elevation & RMSE (\%) \\
\hline TDEM-1 & 485153 & 552067 & 724 & 1.85 \\
TDEM-2 & 485169 & 551802 & 715 & 3.09 \\
TDEM-3 & 485198 & 551576 & 710 & 1.31 \\
TDEM-4 & 485224 & 551410 & 718 & 5.62 \\
TDEM-5 & 485448 & 551407 & 705 & 3.88 \\
TDEM-6 & 485453 & 551573 & 703 & 6.74 \\
TDEM-7 & 485498 & 551740 & 703 & 1.58 \\
TDEM-8 & 485685 & 551830 & 735 & 2.75 \\
TDEM-9 & 485686 & 551584 & 740 & 4.61 \\
TDEM-10 & 485681 & 551331 & 735 & 5.46 \\
\hline
\end{tabular}


order to avoid aliasing effects of possible galvanic interference. The system is comprising a Transmitter-Receive control and managed by HP-IPAQ Pocket system. TDEM measurements were analyzed using TEM RESEARCHER Software, a component of TEM FAST 48 HPC system. Data were processed by fitting the theoretical model with field data. TEM RESEARCHER Software enables to combine multi TDEM soundings in a 2-D cross section of resistivity distribution. It allows for interpreting TDEM data in a single curve (Figure 4) or in a profile of multi TDEM soundings (Figures 5-10).

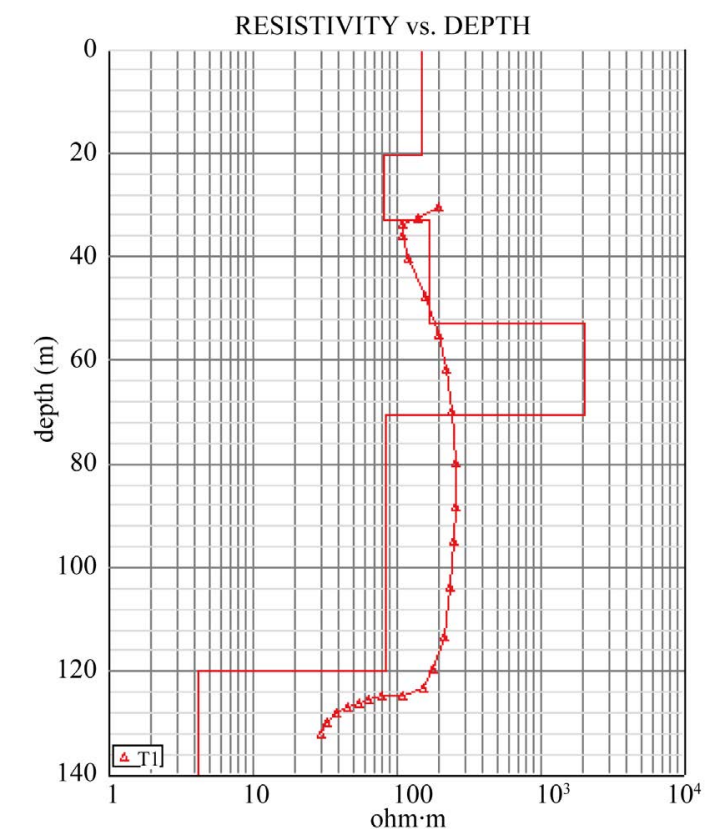

(a)

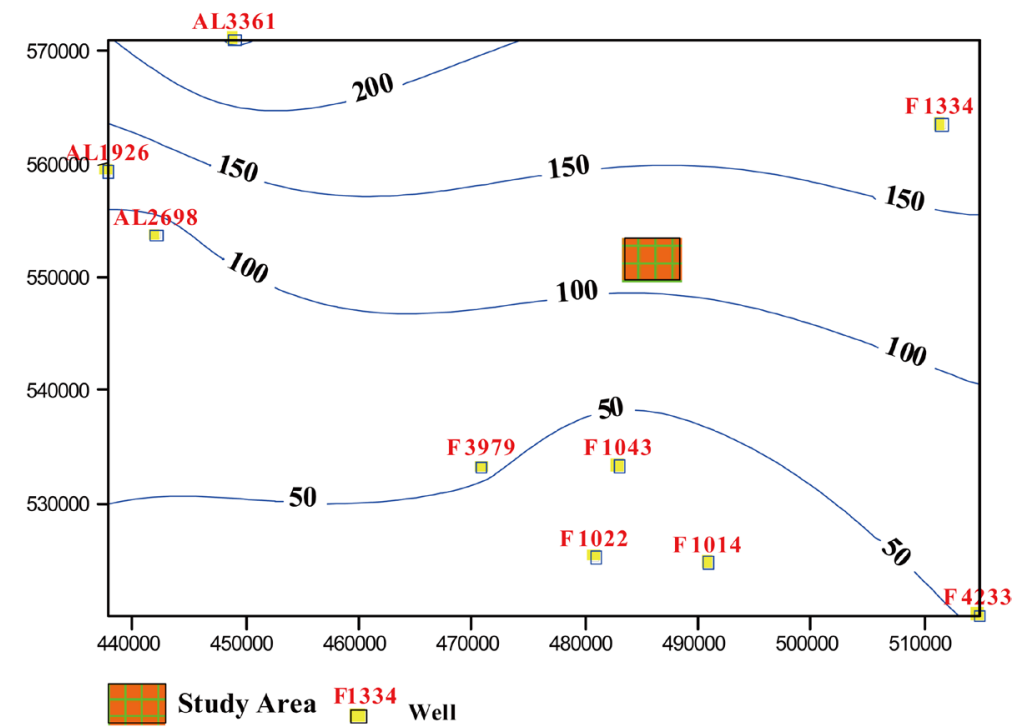

(b)

Figure 4. (a) An example of a 1-D layering model and measured curve of TDEM-1 (the figure shows the variations of resistivity with depth and inverted model of TDEM-1) (RMES $=1.8 \%$, see Table 2 for interpretation). At depth $120 \mathrm{~m}$ below ground surface, the resistivity is abruptly declining to reach $30 \mathrm{ohm} \cdot \mathrm{m}$ which could be ascribed to groundwater aquifer (see Figure 4(b)); (b) Static water level map of the basaltic aquifer in the study area and its surrounding. The static water level in the study area is located at depth ranging between countour lines $125 \mathrm{~m}$ and $150 \mathrm{~m}$ below ground surface. This is highly correlated with the results of the inverted model of TDEM's (Figure 4(a)). Data obtained from Ministriy of Water and Irrigation and interpolated using Kriging method. 


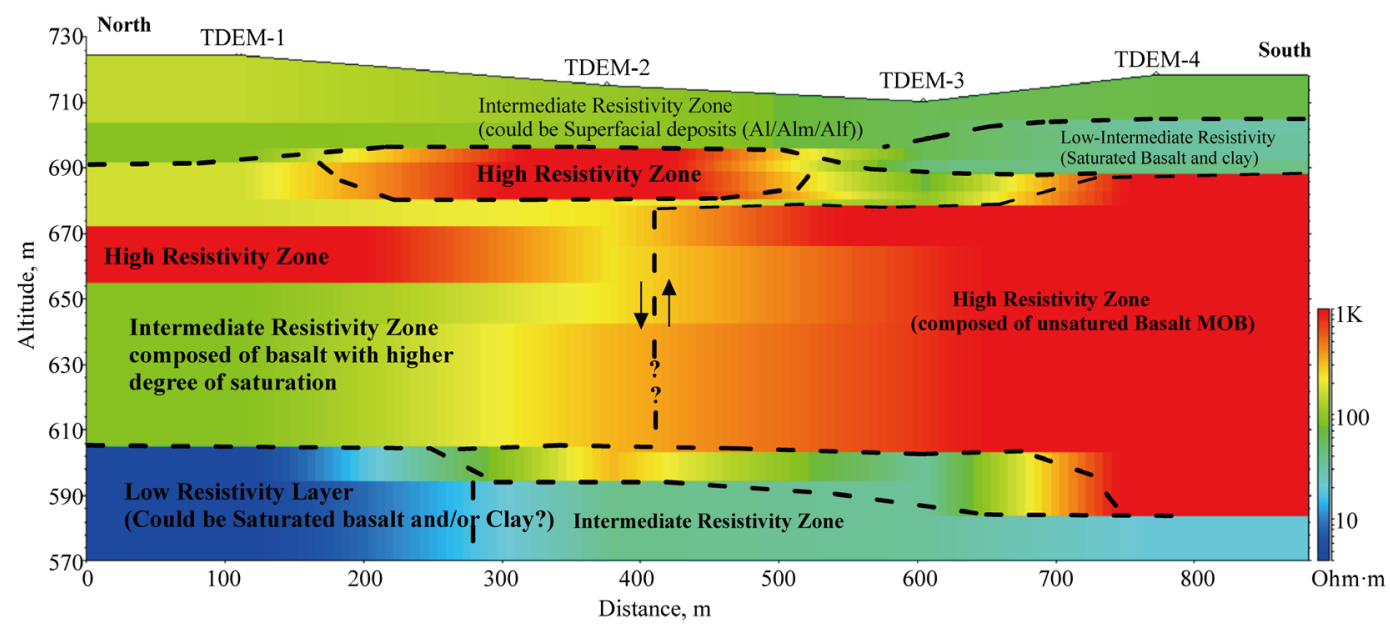

Figure 5. Interpreted hydro-geophysical resistivity model derived from TDEM's soundings, available geological information and static water level map for the study area (Figure 4(b)).

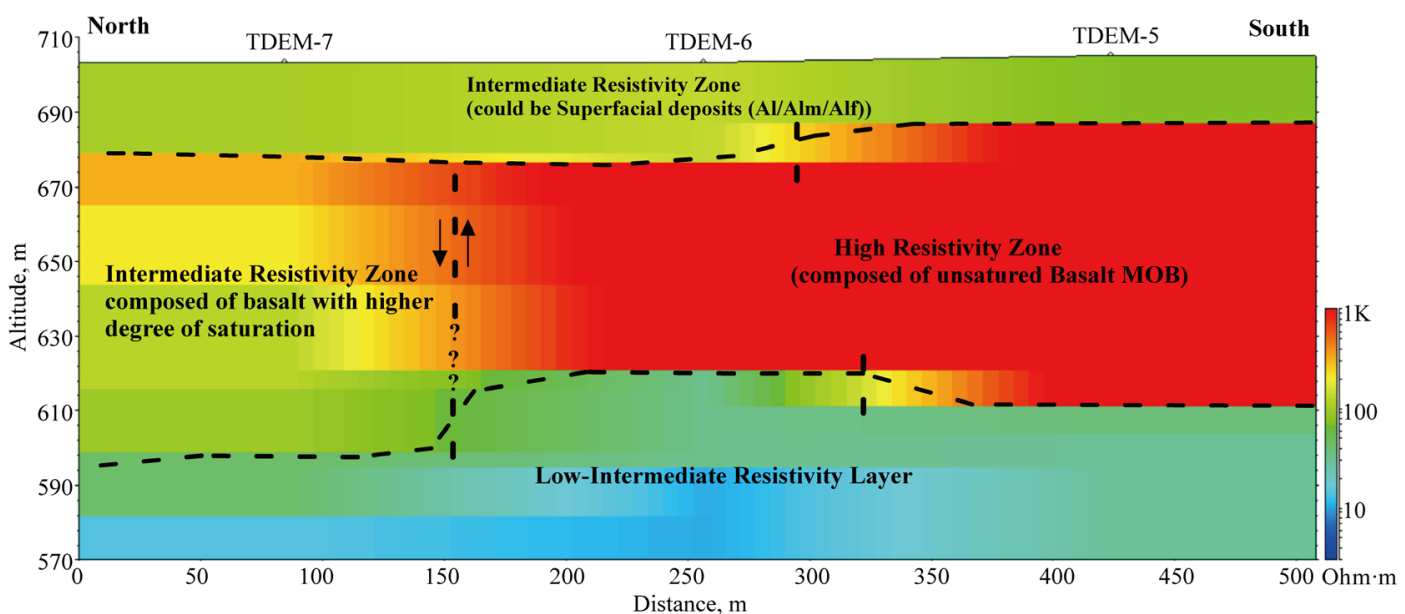

Figure 6. Interpreted hydro-geophysical resistivity model derived from TDEM’s soundings, available geological information and static water level map for the study area (Figure 4(b)).

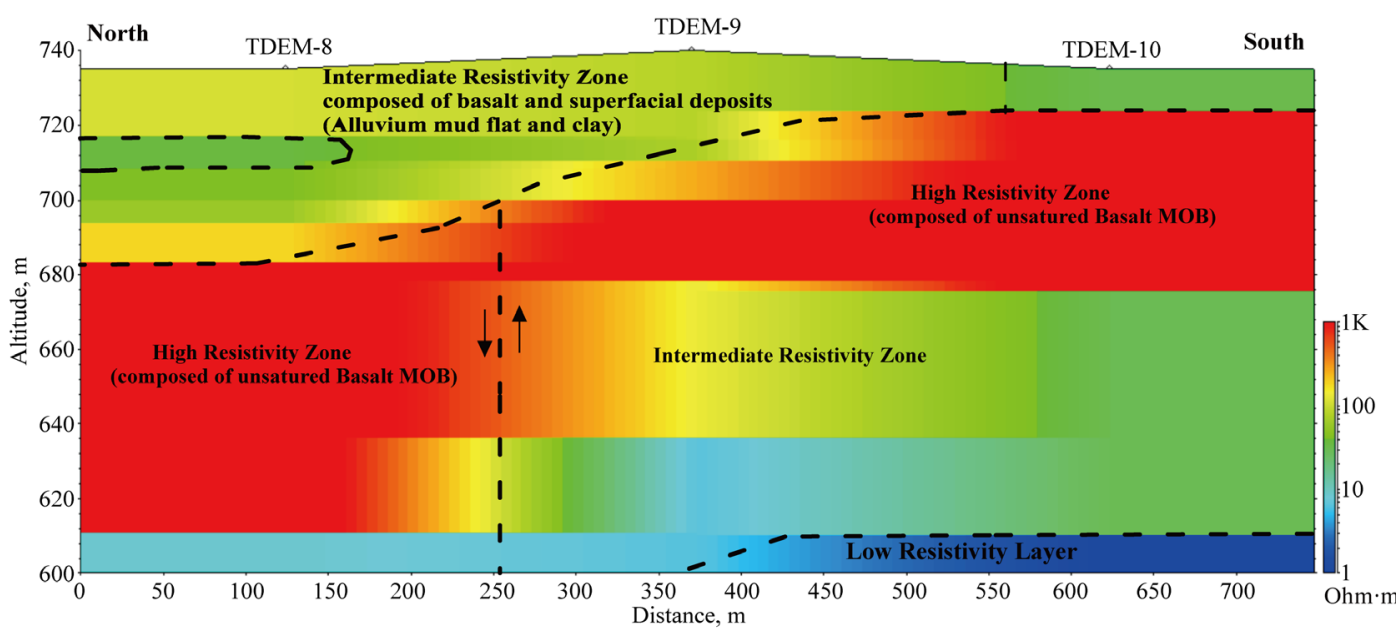

Figure 7. Interpreted hydro-geophysical resistivity model derived from TDEM's soundings, available geological information and static water level map for the study area (Figure 4(b)). 


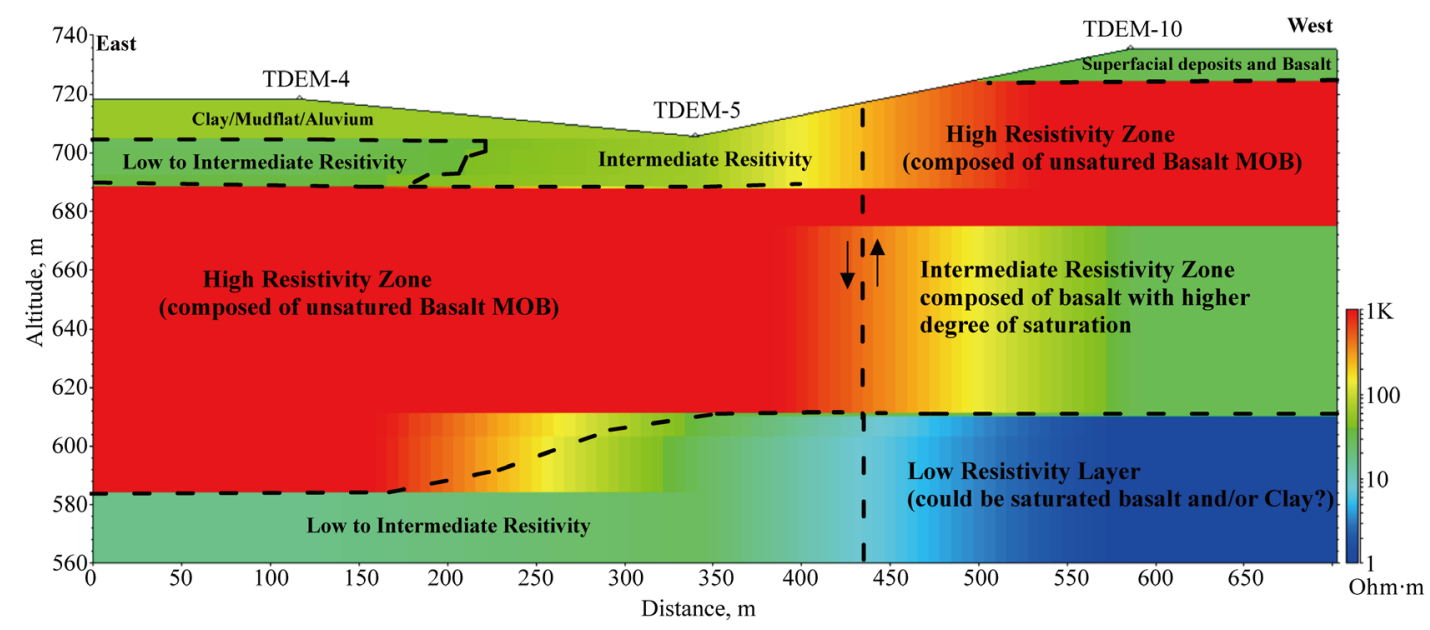

Figure 8. Interpreted hydro-geophysical resistivity model derived from TDEM's soundings, available geological information and static water level map for the study area (Figure 4(b)).

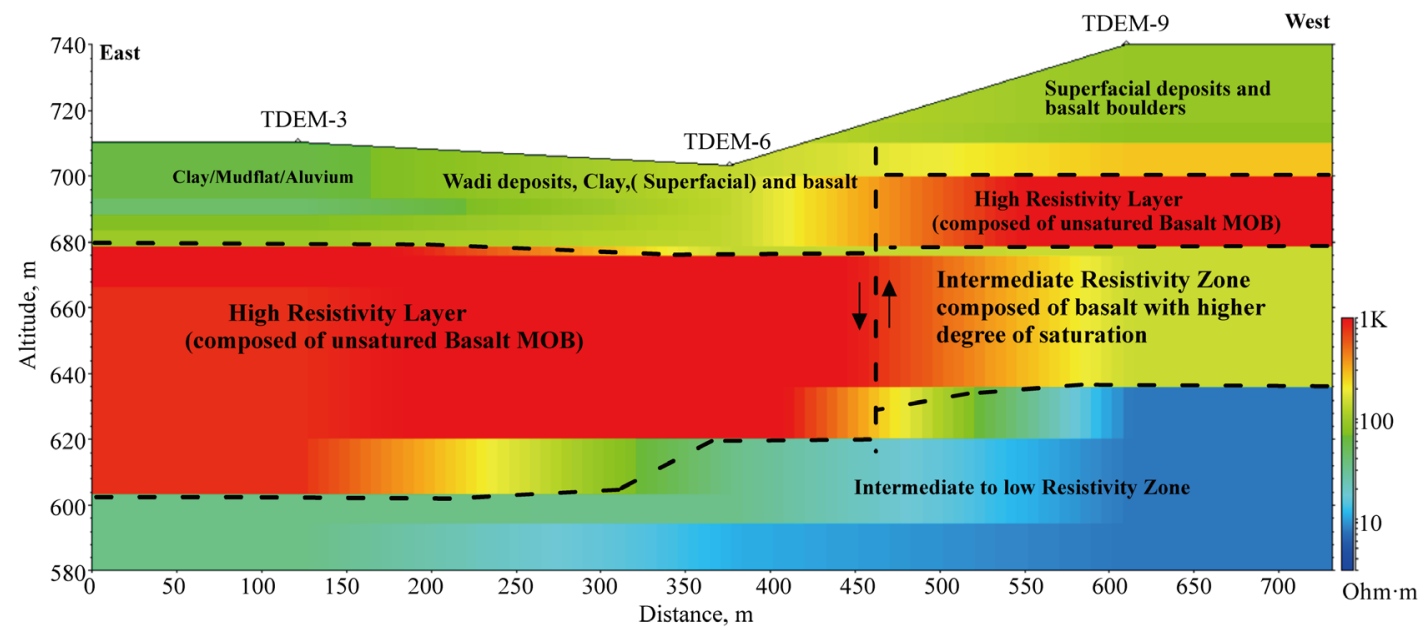

Figure 9. Interpreted hydro-geophysical resistivity model derived from TDEM’s soundings, available geological information and static water level map for the study area (Figure 4(b)).

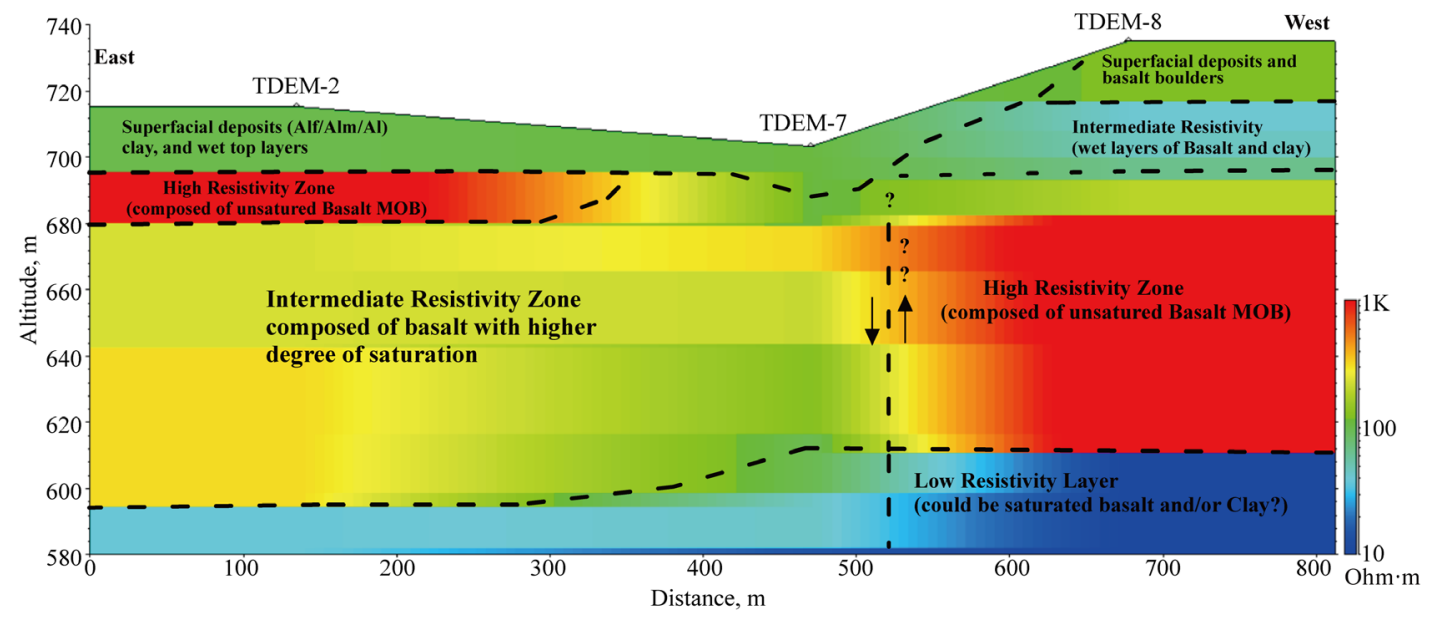

Figure 10. Interpreted hydro-geophysical resistivity model derived from TDEM's soundings, available geological information and static water level map for the study area (Figure 4(b)). 


\section{Results, Discussion and Conclusions}

TDEM's sounding points have been individually interpreted as a 1-D layering model using the available surface and subsurface geological information and the static water level map of basaltic aquifer (Figure 4(a) and Figure 4(b)). Table 2 lists the multi-layering model interpretation for each TDEM sounding point. Figures 5-7 show N-S 2-D resistivity cross-sections and Figures 8-10 show an E-W 2-D resistivity cross-section over the investigated area. In order to facilitate the geological interpretations, the inverted models were typically represented in thematic maps and cross-sections [40]. The resistivity distributions at selected depths (20 m, $75 \mathrm{~m}$ and $120 \mathrm{~m}$ ) are outlined in Figures 11-13 respectively. Figure 14 shows a 3-D resistivity visualization model of TDEM's results. The TDEM's results suggest three principal subsurface layers. The top surface layer has intermediate resistivity values which could be attributed to super facial deposits such as alluvial mud flat (Alm), alluvial fans (Alf), wadi deposits and clay intercalated with basalt boulders. The thickness of this layer is ranging from a few meters to around $50 \mathrm{~m}$ at TDEM-8 and TDEM-4 (Figure 7 and Figure 5). The second subsurface layer has high resistivity values and is composed of unsaturated massive basalt layer. It could belong to MOB of Asfar Group. It is characterized by a variable thickness as shown in different 2-D cross-sections. For instance, it has a thickness of about 100 - $110 \mathrm{~m}$ at TDEM-4 (Figure 5 and Figure 8), $70 \mathrm{~m}$ at TDEM-5 (Figure 6 and Figure 8), and $80 \mathrm{~m}$ at TDEM-8 (Figure 10). Moreover, significant lateral variations in the resistivity of this layer were apparent. It has a resistivity of $90-100 \Omega \cdot \mathrm{m}$ at TDEM-1, TDEM-2 (Figure 5), TDEM-7 (Figure 6), TDEM-9 and TDEM-10 (Figure 7) and it was identified as an intermediate resistivity zone composed of basalt with higher

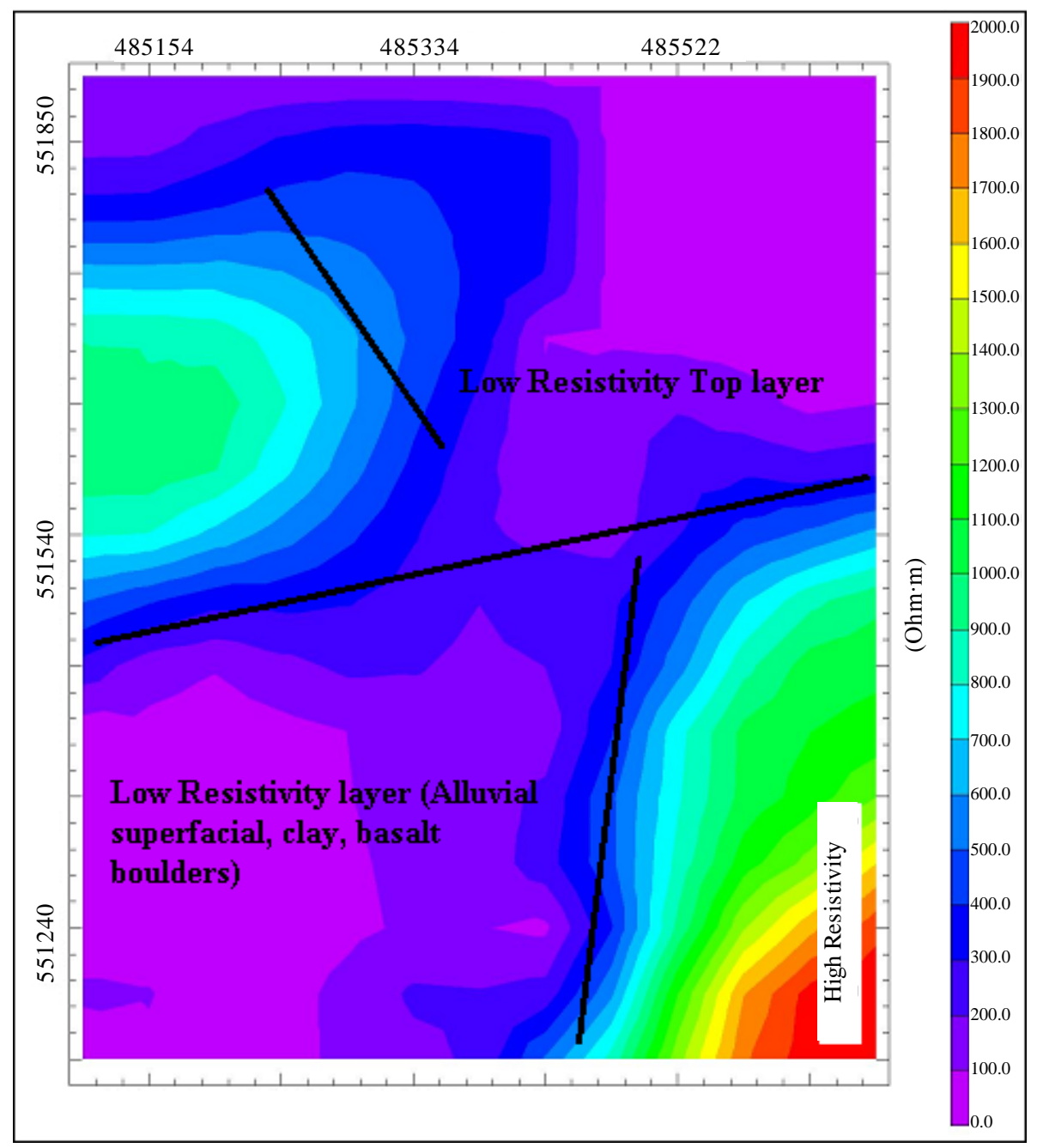

Figure 11. Resistivity map at a depth of 20 m below ground surface. Coordinates System: JTM. 
Table 2. Multilayer interpretation of TDEM's soundings.

\begin{tabular}{|c|c|c|c|c|}
\hline Sounding & Layer & $\begin{array}{l}\text { Resistivity } \\
(\text { Ohm?m) }\end{array}$ & Thickness (m) & Suggested Geological Interpretation \\
\hline \multirow[t]{7}{*}{ TDEM-1 } & 1 & 145.8 & 20.2 & \\
\hline & 2 & 80.6 & 12.3 & \multirow[t]{2}{*}{$\begin{array}{l}\text { Intermediate resistivity top soil } \\
\text { (could be superfacial deposits, } \mathrm{Alm} / \mathrm{Alf} / \mathrm{Al} \text { and clay) }\end{array}$} \\
\hline & 3 & 165.4 & 20 & \\
\hline & 4 & 2000 & 17.5 & \multirow[t]{2}{*}{ High resistivity layer composed of unsaturated basalt of MOB } \\
\hline & 5 & 82.4 & 10 & \\
\hline & 6 & 4.06 & 20 & \multirow[b]{2}{*}{ Low resistivity layer (Saturated basalt and clay) Unknown thickness } \\
\hline & 7 & 4.06 & & \\
\hline \multirow[t]{6}{*}{ TDEM-2 } & 1 & 97.99 & 19.6 & $\begin{array}{l}\text { Intermediate resistivity top soil (could be superfacial deposits, } \\
\text { Alm/Alf/Al and clay) }\end{array}$ \\
\hline & 2 & 2000 & 15.24 & High resistivity layer composed of unsaturated basalt of MOB \\
\hline & 3 & 229.13 & 38.17 & \multirow{2}{*}{$\begin{array}{l}\text { Intermediate resistivity layer composed of Basalt with higher degree } \\
\text { of saturation }\end{array}$} \\
\hline & 4 & 309.56 & 10 & \\
\hline & 5 & 37.85 & 30 & Low-intermediate resistivity layer \\
\hline & 6 & 37.85 & & Low-intermediate resistivity layer (unknown thickness) \\
\hline \multirow[t]{8}{*}{ TDEM-3 } & 1 & 57.8 & 17.7 & \\
\hline & 2 & 42 & 4 & \multirow{3}{*}{$\begin{array}{l}\text { Intermediate resistivity top soil (could be superfacial deposits, } \\
\mathrm{Alm} / \mathrm{Alf} / \mathrm{Al} \text { and clay) }\end{array}$} \\
\hline & 3 & 68.2 & 5.53 & \\
\hline & 4 & 94.2 & 4.57 & \\
\hline & 5 & 1672 & 12.5 & \multirow{2}{*}{ High resistivity layer composed of unsaturated basalt of $\mathrm{MOB}$} \\
\hline & 6 & 760.8 & 63.1 & \\
\hline & 7 & 33.6 & 10 & $\begin{array}{l}\text { Intermediate to low resistivity top soil } \\
\text { (could be saturate basalts and clay) }\end{array}$ \\
\hline & 8 & 9.87 & & Low resistivity with unknown thickness \\
\hline \multirow[t]{7}{*}{ TDEM-4 } & 1 & 64.4 & 13.8 & \\
\hline & 2 & 29.6 & 3.78 & \multirow{2}{*}{$\begin{array}{l}\text { Intermediate to low resistivity top soil } \\
\text { (could be saturate basalts and clay) }\end{array}$} \\
\hline & 3 & 32.3 & 8.14 & \\
\hline & 4 & 38.9 & 4.49 & \\
\hline & 5 & 1430 & 11.2 & \multirow{3}{*}{ High resistivity layer composed of unsaturated basalt of MOB } \\
\hline & 6 & 2000 & 23.8 & \\
\hline & 7 & 19.6 & & \\
\hline \multirow[t]{5}{*}{ TDEM-5 } & 1 & 70 & 18.1 & Intermediate resistivity \\
\hline & 2 & 2000 & 76 & \multirow[t]{2}{*}{ High resistivity layer composed of unsaturated basalt of MOB } \\
\hline & 3 & 38 & 7.58 & \\
\hline & 4 & 26 & 20 & Low-intermediate resistivity layer (thickness $>30 \mathrm{~m}$ ) \\
\hline & 5 & 23.3 & & \\
\hline
\end{tabular}




\section{Continued}

\begin{tabular}{|c|c|c|c|c|}
\hline \multirow[t]{7}{*}{ TDEM-6 } & 1 & 133.3 & 27.18 & $\begin{array}{l}\text { Intermediate resistivity top soil (could be superfacial deposits, } \\
\text { Alm/Alf/Al and clay) }\end{array}$ \\
\hline & 2 & 2000 & 56 & High resistivity layer composed of unsaturated basalt of MOB \\
\hline & 3 & 32.56 & 26.3 & \multirow{2}{*}{$\begin{array}{l}\text { Low-intermediate resistivity layer } \\
\text { (thickness }>30 \mathrm{~m} \text { ) }\end{array}$} \\
\hline & 4 & 10.93 & 10 & \\
\hline & 5 & 3.1 & 20 & \multirow{3}{*}{ Low resistivity layer (thickness > 20 m) } \\
\hline & & & & \\
\hline & 6 & 3.1 & & \\
\hline \multirow[t]{8}{*}{ TDEM-7 } & 1 & 106.5 & 24.4 & \multirow{4}{*}{$\begin{array}{l}\text { Intermediate resistivity top soil (could be superfacial deposits, } \\
\text { Alm/Alf/Al and clay) }\end{array}$} \\
\hline & 2 & 311.7 & 13.7 & \\
\hline & 3 & 207 & 22 & \\
\hline & 4 & 123.8 & 27 & \\
\hline & 5 & 95.5 & 17.8 & \multirow{2}{*}{$\begin{array}{l}\text { Intermediate resistivity layer composed of Basalt with higher degree of } \\
\text { saturation }\end{array}$} \\
\hline & 6 & 43.3 & 10 & \\
\hline & 7 & 14.4 & 10 & Low-intermediate resistivity \\
\hline & 8 & 14.4 & & (resistivity > 15 m) \\
\hline \multirow[t]{7}{*}{ TDEM-8 } & 1 & 117 & 18.6 & \multirow{3}{*}{$\begin{array}{l}\text { Intermediate resistivity zone composed of basalt and superfacial } \\
\text { deposits (alluvium mudflat and clay) }\end{array}$} \\
\hline & 2 & 42 & 16.7 & \\
\hline & 3 & 64 & 6.54 & \\
\hline & 4 & 188.6 & 10.6 & \multirow{3}{*}{ High resistivity layer composed of unsaturated basalt of MOB } \\
\hline & & & & \\
\hline & 5 & 2000 & 50 & \\
\hline & 6 & 10.1 & & $\begin{array}{l}\text { Low resistivity layer with unknown thickness } \\
\text { (saturated layer and clay) }\end{array}$ \\
\hline \multirow[t]{7}{*}{ TDEM-9 } & 1 & 87.3 & 24 & \multirow{2}{*}{$\begin{array}{l}\text { Intermediate resistivity zone composed of basalt and superfacial } \\
\text { deposits (alluvium mudflat and clay) }\end{array}$} \\
\hline & 2 & 78.5 & 5.84 & \\
\hline & 3 & 267.2 & 10.4 & \multirow[b]{2}{*}{ High resistivity layer composed of unsaturated basalt of MOB } \\
\hline & 4 & 2000 & 216 & \\
\hline & 5 & 141 & 10 & Intermediate resistivity \\
\hline & 6 & 7.57 & 20 & Low resistivity layer (saturated layer) \\
\hline & 7 & 7.57 & & Unknown thickness \\
\hline \multirow[t]{5}{*}{ TDEM10 } & 1 & 34.39 & 11.2 & $\begin{array}{l}\text { Intermediate resistivity zone composed of basalt and superfacial } \\
\text { deposits (alluvium mudflat and clay) }\end{array}$ \\
\hline & 2 & 2000 & 49 & High resistivity layer composed of unsaturated basalt of MOB \\
\hline & 3 & 33.34 & 10 & \multirow{3}{*}{$\begin{array}{l}\text { Low resistivity layer (saturated layer) } \\
\text { Unknown thickness }\end{array}$} \\
\hline & 4 & 1.31 & 30 & \\
\hline & 5 & 1.31 & & \\
\hline
\end{tabular}




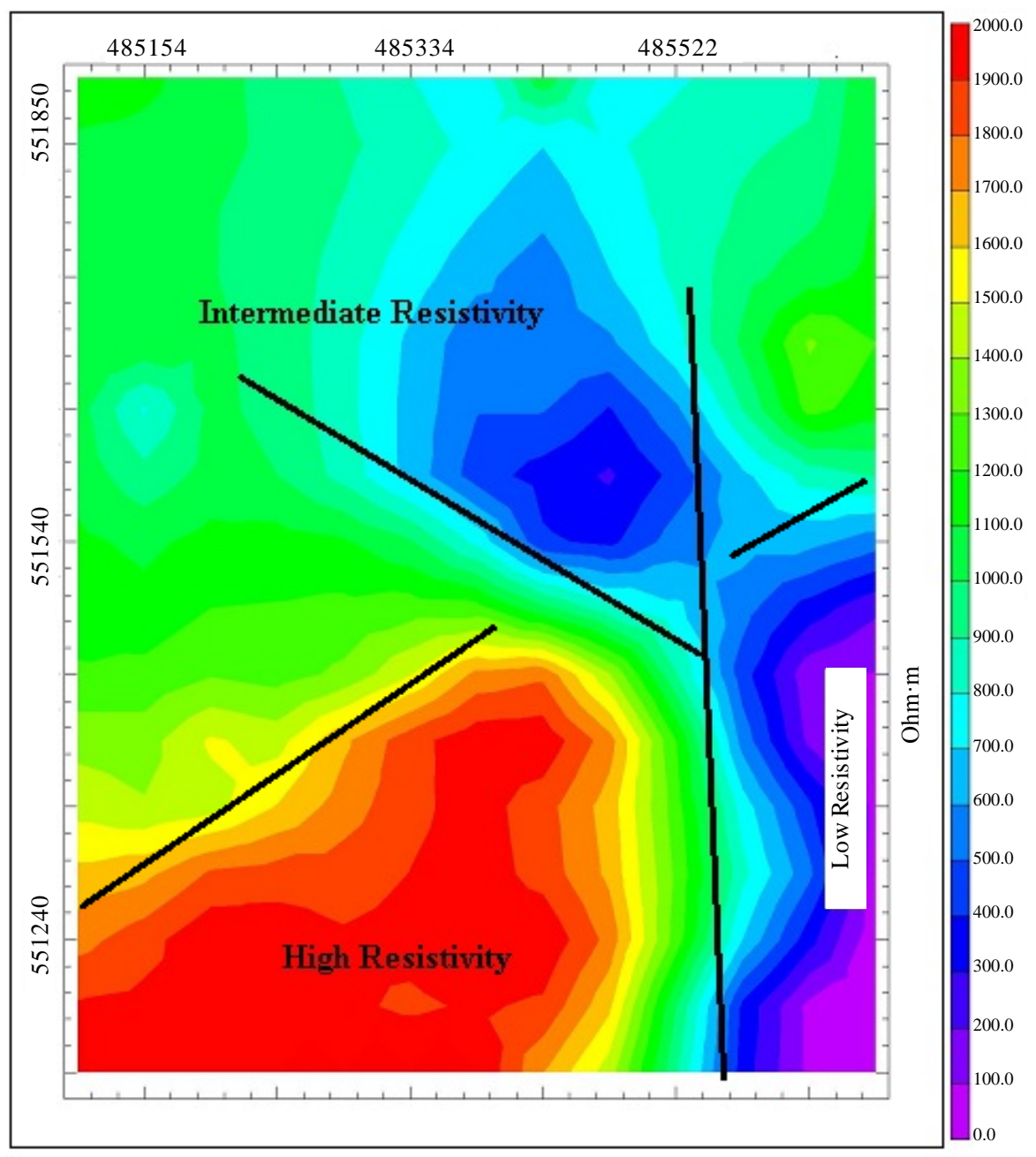

Figure 12. Resistivity map at a depth of $75 \mathrm{~m}$ below ground surface. Coordinates System: JTM.

degree of saturation. Additionally, it was found that the same layer has a resistivity of $1000 \Omega \cdot \mathrm{m}$ at TDEM-3 and TDEM-4 (Figure 5), TDEM-5 and TDEM-6 (Figure 6) and TDEM-8 (Figure 7). The large variation in resistivity could be ascribed to the degree water saturation as a result of groundwater recharge from the nearby harvested water dam, or due to lithological variations (clay content) or structural control. The third subsurface layer was with low resistivity values and observed in the majority of TDEM's soundings and the bottom of the hydro-geophysical cross-sections (Figures 5-10). It was also observed in the 3-D model visualization (Figure 14). This layer was found at depths ranging from 120 to $150 \mathrm{~m}$ below ground surface in the investigated area, and has resistivity values ranging from $<10 \Omega \cdot \mathrm{m}$ to $40 \Omega \cdot \mathrm{m}$. This layer could be interpreted as a saturated basalt layer and/or containing high ratio of clay. In addition, several lenses-like zones have been identified with different resistivities at different depths, which reflect the nature of basalt flow successions and subsurface structures.

There is probably a significant NNW-SSE fault identified at different cross-sections, between TDEM-7 and TDEM-8 (Figure 10), between TDEM-6 and TDEM-9 (Figure 9), and between TDEM-5 and TDEM-10 (Figure 8). It can be seen also in the thematic maps (Figures 11-13). This fault is extending along the course of the downstream valley of Alasra dam site. Moreover, it could be the extension of the well-known Fuluq fault when compared with the surface geological map (Figure 2). This fault is likely to play an important role in groundwater recharge through percolation of surface water into the groundwater aquifer through conduits and fractures. A principal NW-SE fault is probably found between the TDEM-9 and TDEM-10 soundings (Figure 7), between TDEM-6 and TDEM-7 (Figure 6), and below TDEM-2 (Figure 5). It can also be seen in the the- 


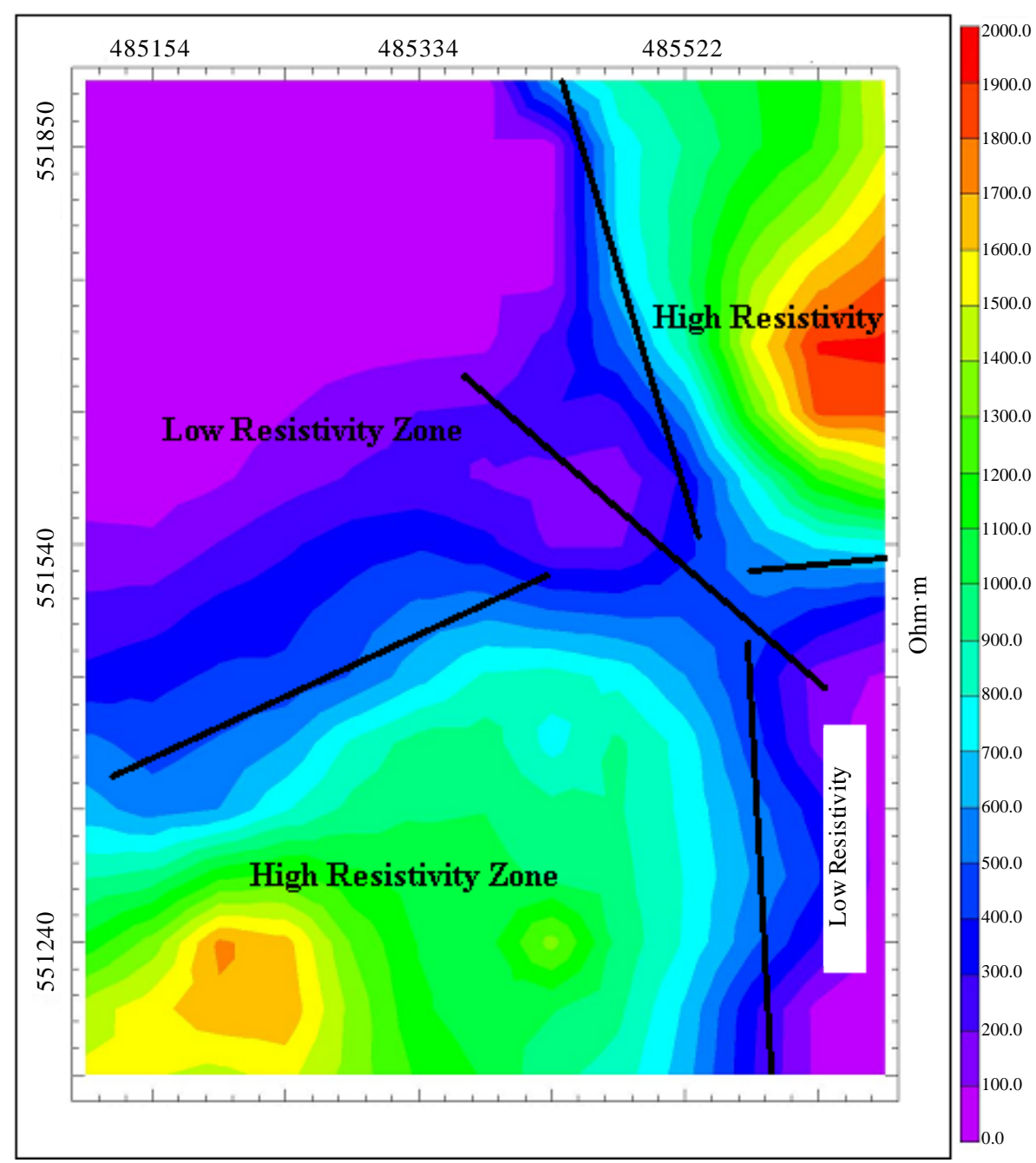

Figure 13. Resistivity map at a depth of $120 \mathrm{~m}$ below ground surface. Coordinates System: Jordan Transverse Mercator (JTM).

matic maps at different depths (Figure 12 and Figure 13). A NE-SW fault extending over the investigated area has been identified and is clearly shown in thematic maps (Figures 11-13).

\section{Artificial Groundwater Recharge Potentiality}

There are several artificial groundwater techniques that have been developed and applied in various parts of the world. The description of these methods is mentioned in [41]-[43]. Based on the resulted hydro-geophysical models, structural pattern and interpreted multi-layering models at downstream of Alasra dam site, the techniques that could be utilized within the study area are:

1) Direct Surface Recharge: It is the simplest and most widely applied technique. In this method, water moves from the land surface to the aquifer by means of percolation through the soil. It has relatively low construction costs and is easy to operate and maintain. However, this technique cannot be applied in the study area for the following reasons:

a) It requires longer time for the recharge water to reach the aquifer. This might lead to evaporation problem, especially in arid environment as that of the study area, where the evaporation rate is high.

b) The groundwater aquifer in the study area is deep (above $150 \mathrm{~m}$ ) which means that the surface water will need more time to reach the groundwater.

c) There are indications of a clay layer above the water table in the study area which prevents the groundwater 


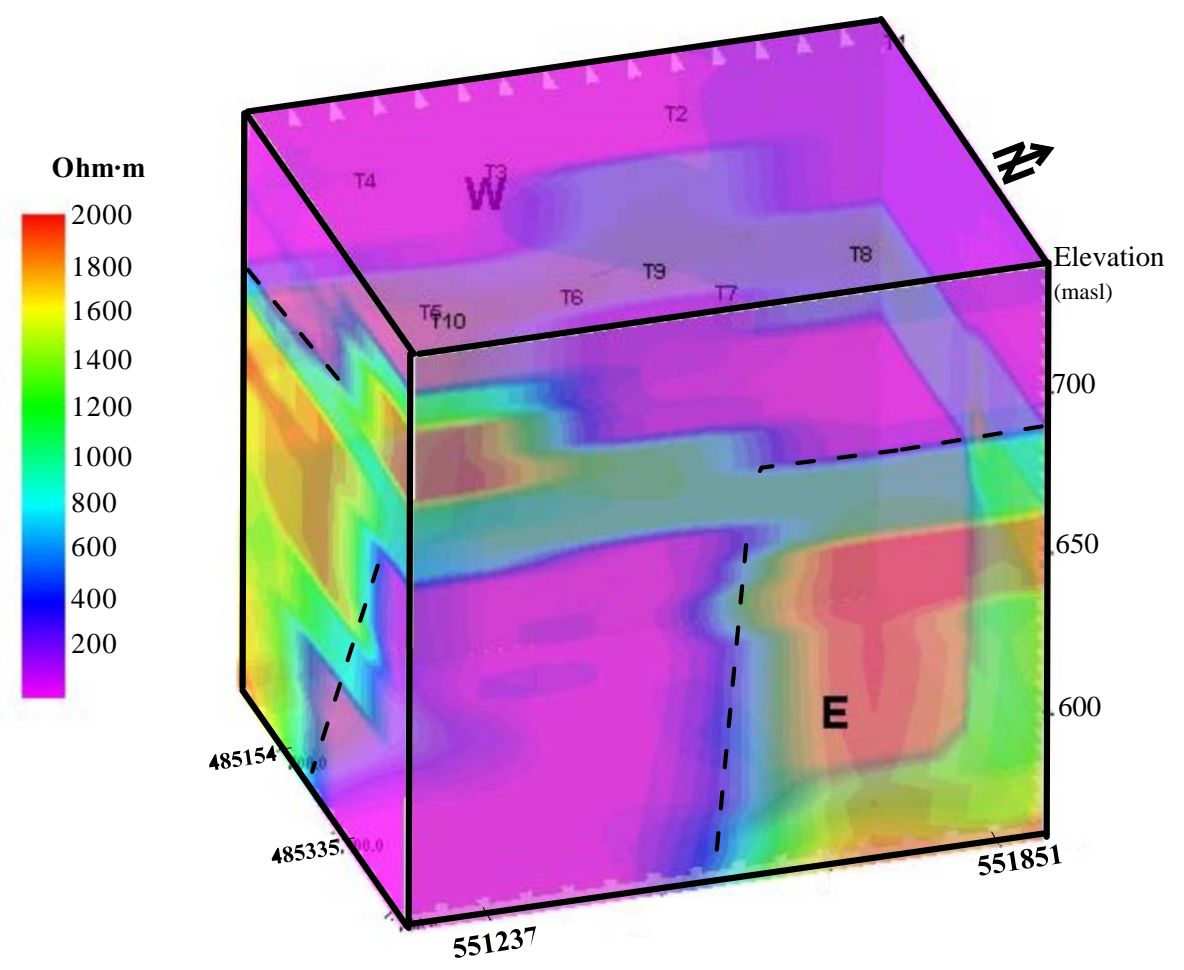

Figure 14. A 3-D resistivity model of the investigated area (downstream of Alasra Dam site). Coordinates System: JTM.

recharge using such technique.

2) Direct Subsurface Recharge: This technique is used for recharging deeper aquifers which is the case within the study area. It is based on digging injection wells when aquifers are deep and separated from the land surface by low permeability materials. This technique is expensive but might be a solution to replenish groundwater in the study area. The problem with the clay layer above the groundwater table can be overcome by digging injection wells to penetrate this layer and establish a path between surface and the groundwater.

3) Combining Surface-Subsurface Methods: Both techniques mentioned above could be combined to have a better groundwater recharge. The surface water dam in the area could help in applying a direct surface recharge through the wadi bed. Also, having injection wells close to the dam will accelerate and maximize the potentials for replenishing the groundwater in the area.

\section{Acknowledgements}

This research was carried out by Hani Al-Amoush while on sabbatical leave from Al al-Bayt University for the academic year (2015/2016). The authors would like to thank Al al-Bayt university presidency, the dean of Institute of Earth and Environmental Sciences. The authors also acknowledge the help and supports of the dean and staff of The Scientific Research Deanship at Al al-Bayt University. Critical and constructive review of the manuscript by the reviewers is greatly treasured.

\section{References}

[1] Salameh, E. and Bannayan, H. (1993) Water Resources of Jordan. Present Status and Future Potentials, Fridrich Ebert Stiftung, Amman, Jordan.

[2] Salameh, E. (1996) Water Quality Degradation in Jordan. Friedrich Elbert Stifing (FES) and Royal Society for Conservation of Nature (RSCN), Amman.

[3] Al Ayyash, S., Al-Adamat, R., Al-Amoush, H.R., Al-Meshan, O., Rawjefih, Z., Shdeifat, A., Al-Harahsheh, A. and Al-Farajat, M. (2012) Runoff Estimation for Suggested Water Harvesting Sites in the Northern Jordanian Badia. Journal. Water Resources and Protection, 4, 127-132. http://dx.doi.org/10.4236/jwarp.2012.43015 
[4] Al-Amoush, H.R. (2012) Hydro-Geophysical Investigations for the Purposes of Groundwater Artificial Recharge in Wadi Al-Butum Area, Jordan. Journal of Water Resource and Protection, 4, 507-515. http://dx.doi.org/10.4236/jwarp.2012.47059

[5] Batayneh, A., Al Zoubi, A. and Abueladas, A. (2001) Geophysical Investigations for the Location of a Proposed Dam in Al Bishriyya (Al Aritayn) Area, Northeast Badia of Jordan. Environmental Geology, 40, 918-922. http://dx.doi.org/10.1007/s002540100270

[6] Al-Adamat, R.A., AlAyyash, S., Al-Amoush, H.R., Al-Meshan, O., Rawajfih, Z., Shdeifat, A., Al-Harahsheh, A. and Al-Farajat, A. (2012) The Combination of Indigenous Knowledge and Geo-Informatics for Water Harvesting Siting in the Jordanian Badia. Journal of Geographic Information System, 4, 366-376. http://dx.doi.org/10.4236/jgis.2012.44042

[7] Bedrosian, M., Burgress, M. and Nishikawa, T. (2013) Faulting and Groundwater in Desert Environment: Constraining Hydrogeology Using Time-Domain Electromagnetic Data. Near Surface Geophysics, 11, 545-555. http://dx.doi.org/10.3997/1873-0604.2013043

[8] Al-Amoush, H.R. (2006) Hydro-Geophysical Investigations for the Purposes of Groundwater Artificial Recharge in the Jordan Valley Area. Ph.D. Dissertation, University of Jordan, Amman.

[9] Al-Amoush, H. (2010) Integration of Vertical Electrical Sounding and Aeromagnetic Data Using GIS Techniques to Assess the Potential of Unsaturated Zone and Natural Basalt Caves for Groundwater Artificial Recharge in NE-Jordan. Jordan Journal for Civil Engineering, 4, 389-408.

[10] Hammouri, N., Al-Amoush, H., Al-Raggad, M. and Harahsheh, S. (2013) Groundwater Recharge Zones Mapping Using GIS: A Case Study in Southern Part of Jordan Valley, Jordan. Arabian Journal of Geosciences.

[11] Al-Amoush, H.R., Al-Adamat, A., AlAyyash, S., Al-Meshan, O., Rawjefih, Z., Shdeifat, A., Al-Harahsheh, A. and Al-Farajat, M. (2012) Preliminary Geophysical Investigation for Suggested Water Harvesting Sites in the Northern Jordanian Badia. Research Journal of Environmental and Earth Sciences, 4, 560-569.

[12] Al-Shabeeb, A. (2015) A Modified Analytical Hierarchy Process Methods to Select Sites for Groundwater Recharge in Jordan. Unpublished PhD Thesis, Leicester University, Leicester, 204 p.

[13] Salameh, E. (2001) The Potential of Groundwater Artificial Recharge in the Jordan Valley Area/Jordan: Selected Contributions to Applied Geology in the Jordan Rift Valley. Freiberger Forschungshefte C494, Freiberg, 1, 63-81.

[14] Fitterman, D. and Stewart, M. (1986) Transient Electromagnetic Sounding for Groundwater. Geophysics, 51, 9951005. http://dx.doi.org/10.1190/1.1442158

[15] Bauer-Gottwein, P., Gondwe, B., Christiansen, L., Herckenrath, D., Kgotlhang, L. and Zimmermann, S. (2009) Hydrogeophysical Exploration of Three-Dimensional Salinity Anomalies with the Time-Domain Electromagnetic Method (TDEM). Journal of Hydrology, 380, 318-329. http://dx.doi.org/10.1016/j.jhydrol.2009.11.007

[16] Duque, C., Calvache, M., Pedrera, A., Martin-Rosales, W. and Lopez-Chicano, M. (2008) Combined Time Domain Electromagnetic Soundings and Gravimetry to Determine Marine Intrusion in a Detrital Coastal Aquifer (Southern Spain). Journal of Hydrology, 349, 536-547. http://dx.doi.org/10.1016/j.jhydrol.2007.11.031

[17] Ferre, T., Bentley, L., Binley, A., Linde, N., Kemna, A., Singha, K., Holliger, K., Huisman, J. and Minsley, B. (2009) Critical Steps for the Continuing Advancement of Hydro Geophysics. EOS, Transactions, American Geophysical Union, 90, 200-201. http://dx.doi.org/10.1029/2009EO230004

[18] Goldman, M., Gilad, D., Ronen, A. and Melloul, A. (1991) Mapping of Seawater Intrusion into the Coastal Aquifer of Israel by the Time Domain Electromagnetic Method. Geoexploration, 28, 153-174. http://dx.doi.org/10.1016/0016-7142(91)90046-F

[19] Herckenrath, D., Odlum, N., Nenna, V., Knight, R., Auken, E. and Bauer-Gottwein, P. (2013) Calibrating a Salt Water Intrusion Model with Time-Domain Electromagnetic Data. Groundwater, 51, 385-397.

[20] Al-Amoush, H., Al-Tarazi, E., Abu Rajab, J., Al-Dwyeek, Y., Al-Atrash, M. and Shudiefat, A. (2015) Geophysical Investigation Using Time Domain Electromagnetic Method (TDEM) at Wadi Deir Al-Kahaf Area/Jordan for Groundwater Artificial Recharge Purposes. Journal of Water Resource and Protection, 7, 143-151. http://dx.doi.org/10.4236/jwarp.2015.73012

[21] Minsley, B.J., Ajo-Franklin, J., Mukhopadhyay, A. and Morgan, F.D. (2011) Hydro Geophysical Methods for Analyzing Aquifer Storage and Recovery Systems. Groundwater, 49, 250-269. http://dx.doi.org/10.1111/j.1745-6584.2010.00676.x

[22] Lartet, L. (1896) La geologie de la Palastine. Thesis, University of Paris, Messon, 292 p.

[23] Van Den Boom, G. and Sawan, O. (1966) Report on Geological and Petrological Studies of the Plateau Basalts in NE-Jordan. German Geological Mission, Amman, 42 p.

[24] Bender, F. (1974) Geology of Jordan. Borntraeger, Berlin, 196 p.

[25] Baraberi, F., Capaldi, G., Gasperini, P., Marinelli, G., Santacroce, R., Scandone, R., Treuil, M. and Varet, J. (1979) 
Recent Basaltic Volcanism of Jordan and Its Implications on the Geodynamic Evolution of the Afro-Arabian Rift System. Accademia Nazionale Dei Lincei, Atti Del Corvegni Lincei, 74, 667-683.

[26] Ibrahim, K. (1987) Geochemistry and Petrology of Some of the Basaltic Outcrops in Central Jordan. MSc Thesis, University of Jordan, Amman, $164 \mathrm{p}$.

[27] Moffat, D. (1988) A Volcano Tectonic Analysis of the Cenozoic Continental Basalts of Northern Jordan; Implications for Hydrocarbon Prospecting in the Block B Area. ERI Jordan EJ88-1, 73 p.

[28] Al-Malabeh, A. (1989) The Volcanic Succession of Jebel Aritayn Volcano, NE-Jordan: A Field Petrographic and Geochemical Study. MSc Thesis, Yarmouk University, Irbid, 182 p.

[29] Fakhoury, I. (1991) Mineralogy, Phase-Petrology and Geochemistry of Mafic and Ultramafic Xenoliths in the Quaternary Basalts, NE Jordan. MSc Thesis, Yarmouk University, Jordan, 155 p.

[30] Khalil, I. (1991) Geochemische und petrographische untersuchungen an Tertaren bis Quarteren kontinintalen intraplattenbassalten Nordost-Jordanien. PhD Thesis, Technische Universität Clausthal, Clausthal-Zellerfeld, Germany, 119 p.

[31] Al-Malabeh, A. (1993) The Volcanology, Mineralogy, and Geochemistry of Selected Pyroclasric Cones from NEJordan and Their Evaluation for Possible Industrial Applications. PhD Thesis, Universitat Erlangen, Nurnberg, 300 p.

[32] Al-Malabeh, A. (1994) Geochemistry of Two Volcanic Cones from the Intra-Continental Plateau Basalt of Harra El Jabban, NE-Jordan. Geochemical Journal, 28, 517-540.

[33] Ibrahim, K. (1993) The Geological Framework for Harrat Ash-Shaam Basaltic Super-Group and Its Volcano Tectonic Evolution. Natural Resources Authority, Geological Mapping Division, Bulletin 25, 33 p.

[34] Ibrahim, K. (1996) The Regional Geology of Al Azraq Area Map Sheet No. 3553I. Natural Resources Authority, Geological Mapping Division, Bulletin 36, 67 p.

[35] Khalil, I. (1997) The Geology of AlBishriyya (Al Arityn) Area, Map Sheet No. 3354 II (with Special Reference to the Geology of the Economic Zeolite Deposits). Geological Mapping Division, Bulletin 39.

[36] Ibrahim, K., Rabba, I. and Tarawneh, K. (2001) Geological and Mineral Occurrences Map of The Northern Badia Region, Jordan, Scale 1:250.000. Geological Mapping Division.

[37] AlAyyash, S., Nnadi, F. and Shatnawi, R. (2008) A Surface Water Management Tool for Arid Lands Using GIS-A Jordan Badia Case Study. In: Dutton, R.W. and Shahbaz, M.I., Eds., Jordan's Arid Badia: Deepening Our Understanding, Smith-Gordon and Company, UK.

[38] Reynolds, J. (1998) An Introduction to Applied and Environmental Geophysics. John Wiley and Sons, Ltd., Chichester, $796 \mathrm{p}$.

[39] Kirsch, R., Ed. (2006) Groundwater Geophysics: A Tool for Hydrogeology. Springer-Verlag, Berlin Heidelberg, 493 p. http://dx.doi.org/10.1007/3-540-29387-6

[40] Jogensen, F., Sandersen, P., Auken, E., Lykke-Andersen, H. and Sorensen, K. (2005) Contributions to the Geological Mapping of Mors, Denmark-A Study Based on a Large Scale TEM Survey. Bulletin of the Geological Society of Denmark, 52, 53-75.

[41] Todd, D. (1980) Groundwater Hydrology. 2nd Edition. John Wiley \& Sons, New York, 535 p.

[42] Huisman, L. and Olsthoorn, T. (1983) Artificial Groundwater Recharge. Pitman Publishing Inc., Marshfield, 320 p.

[43] Asano, T. (1985) Artificial Recharge of Groundwater. Butterworth Publishers, Boston, 767 p. 